\title{
Study of processing for measurement of thyroid stimulating antibody activity (TSAb\%)
}

\author{
名古屋大学医学部附属病院 放射線部 \\ ○植村 武司、亀山 裕司、 \\ (Takeshi Uemura) (Hiroshi Kameyama) \\ 野口＼cjkstart英三 \\ (Hidezou Noguchi)
}

【目的】バセドウ病患者の血液中の甲状腺刺激物質として TSHレセプターに対する甲状腺刺激性自己抗体 （TSAb）の存在が知られています。そこで、我々は無菌的な長時間培盖を必要としないブ夕甲状腺初代細胞 を使用、血清中TSAbの甲状腺細胞に拈けるcAMPの産生量を指標とするTSAbキット「ヤマサ」を用い、キッ トの操作条件による諸特性及び、当院で測定されている関連ホルモン、抗体との相関関係を求め、キットが 日常的に使用可能か検討しました。

【方法】本TSAb活性の測定は、以下の 4 つの行程に分かれています。1) 被検血清及びキット添付のコ ントロール血清の前処理はPEG処理を行い、「IgG分画」を調製します。2）細胞液の調製はブタ甲状腺細 胞液を細胞洗浄液で 2 回洗浄し、「細胞調製液」とします。3）cAMP産生反応はIgG分画」と「細胞調製

液」を反応させます。4）反応液中のcAMP濃度の測定は本TSAb活性測定用の 2 抗体RIA法で行います。

また、TSAb\%は被検血清の「反応液」中のcAMP濃度と同時に測定したコントロール血清の「反応液」中 のcAMP濃度の比により算出されます。

今回の検討項目としては、1) cAMP産生反応時の反応時間、反応温度による影響、2）健常者の正常分 布、3）関連ホルモン等との相関関係について検討しました。

【結果】 反忍時間は 1 及び 2 時間ではcAMP産生量の差が小さく、また 6 及び 8 時間ではcAMP産生に変 動がある検体も見られることから、4 時間と設定しました。

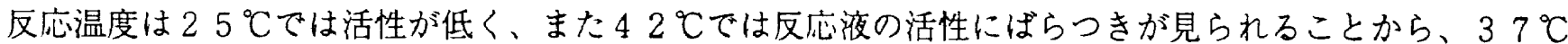
に設定しました。

次に甲状腺ホルモンが正常で、甲状腺関連自己抗体活性陰性の健常 50 人の検体を用いたTSAb活性の分布 は78.7〜185.7\%となりました。また、甲状腺疾患を有する検体116 例を用いて、TSH、FT 3、FT 4 及び TGAgとTSAb活性との相関を求めました。その結果、これらの検査項目とTSAb活性との間に有為な 相関関係は得られませんでした。TBIとTSAb活性との相関は回㷌直線 $\mathrm{Y}=6.61 \mathrm{X}+52.6$ 、相関係数が $\mathrm{r}$ $=0.55$ と弱い相関関係が認められました。

TBIIとTSAb活性が同様に甲状腺のTRAbを対象に測定しているにも関わらず、両検査間の相関性が低いこ との原因として、TSAb活性測定におけるPEG処理操作上の影響について検討を行いました。PEG処理した血 清を用いて、TBII測定した結果、PEG処理していない血清中のTBIとの相関回㷌はY=1.05X-8.15、 相関係数は $\mathrm{r}=0.986$ であり、PEG処理操作によるTSAb活性とTBII との相関関係への影響はないと考えら れました。

弱い相関関係しか認められなかった理由としては、1）TRAbにはTSAb、TSBAb等多様性があり、また $\mathrm{TSAb}$ とSBAbが共存する症例の報告もありTBIとの反応に相違があること、2）雨キットの測定感度や特異 性に相違があることなどが考えられる為、両キットの併用によりバセドウ病の診断能の向上が期待できま す。

【まとめ】細胞の反応時間は 4 時間、反応温度は 37 度と設定しました。健常者の度数分布は $78.7 \sim$ $185.7 \mathrm{TSAb} \%$ でた。TSH、FT3、FT 4 及びTGAgとの間に有為な相関関係は認められませんでした。 TBI亡TSAbとの間に $\mathrm{r}=0.55$ の弱い相関関係が認められました。

【結論】今回使用したキットは測定操作上の注意点が多く、特にブタ細胞の取扱は重要で、低温で素早く 処理する必要があります。また、PEG処理後のIgG分画は非常に溶解しにくいことからガラスビーズを加えて 擋挥するなどの応用も必要であると考えられました。

本TSAbキットは以上のように幾つかの注意が必要ですが、一部の研究室やラボでしか測定できなかった TSAb活性の測定を無菌的培養を必要とせずに、キット化することにより一般的な検査室でもTSAb活性が測 定できる画期的なキットであり、今後のバセドウ病の検査診断に役立つと考えられます。 